図の左よりまず histamine を添加し腸管の収縮が最高に達し弛緩し始めた時直ちに Magnus cup 3 回洗 浄する. 洗浄後 3 分 (最初の histamine 添加より 5 分) と histamine を添加し同様の収縮を描記する。このよ 万に histamine 単独による腸管の収縮が一定となるまで 5 分間隔で 3 4 回繰返えし添加する.ついで検体の 一定量 (図に叔いては $10^{-5} \mathrm{~m} M$ ) 老添加し，2 分後に histamine を添加して検体の存在下に招ける収縮を描記す る. 洗浄後再び histamine 単独を5 分間隔で繰返光し添加すると腸管の収縮度は検体を作用させる前とほぼ同 一の反応性を回復する。このように histamine と検体を交互に添加し同一の腸管に上り一定間隔を有する 3 4 量について検体存在下に怙ける収縮度を描記し，これと検体添加前の histamine 単独の収縮度を比較し抑制率を 求めた。この抑制率をグラフ上にプロットし，ほぼ適合せる值線を引き抑制率が $50 \%$ となる量を求め検体相互間 の比から効力比老求めた。

田辺製薬大阪研究所

UDC $615.778 .475-012: 576.852 .211 .095 .18$

277. (故) 野津龍三郎, 渡邊 熙, 桑田 蕃, 横山脩造 : 結核化学療法の研究 (第 11 報*) 2-Alkoxy-4-aminobenzoic Acid 抢よび 4-Alkylaminosalicylic Acidの合成 並びにとの結核菌に対する抗菌作用

(The late) Ryuzaburo Nodzu, Hiroshi Watanabe, Shigeru Kuwata, and Shuzo Yokoyama : Studies on Chemotherapy of Tuberculosis. XI. Syntheses of 2-Alkoxy-4aminobenzoic Acid and 4-Alkylaminosalicylic Acid, and Their Bacteriostatic Action against Mycobacterium tuberculosis.

(Chemical Institute, Kōnan University**)

Some of 2-alkoxy-4-aminobenzoic acid, 4-alkylaminosalicylic acid, and 2-alkoxy-4nitrobenzoic acid (alkyl = methyl, butyl, octyl, dodecyl, hexadecyl) were prepared and their bacteriostatic action against tubercle bacilli (human type) was tested in Kirchner medium. In these three compound series, it was found, as in other alkyl compounds already reported, that antibacterial activity increased with the number of carbon atoms in the alkyl, reached the maximum at around $\mathrm{C}_{12}$, and decreased again over that number. The dodecyl derivatives of not only PAS but also of 4-nitrosalicylic acid, which by itself showed no remarkable activity, were as strongly antituberculous as PAS. This fact seems to suggest that, in some cases, even non-active compound may aquire strong antitubercular activity by introduction of alkyl group into it. The order of activity was : 4-alkylaminosalicylic acid $>2$-alkoxy-4-aminobenzoic acid $>2$-alkoxy-4-nitrobenzoic acid.

(Received April 21, 1959)

前報で報告した如く, PAS の脂溶性誘導体中飞結核に有効な化合物の岗ることを期待して，その acy1 化合物 を検索した結果，4-lauroylaminosalicylic acid が in vitro で強力な抗結核性を有することを知つた．この臨 桩への応用を試よたが，膿胸の洗浄薬としては著效の認められる例もあつたが，経口投与では良好な結果を得る ことが出来なかつた1)。この原因はあるい怔薬剤が消化管内で加水分解を受けることにあるかも知れないと考光た ので, PAS に, 加水分解され難い形で alkyl 基を導入することを計画し, PAS の O-alkyl おょび N-alkyl

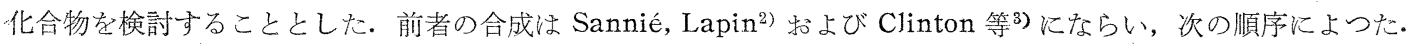<smiles></smiles>

( I )

* 第 10 報: 本誌 $\mathbf{7 6}, 843(1956)$.<smiles>Cc1nc2ccc([N+](=O)[O-])cc2o1</smiles>

$* *$<smiles>Nc1ccc([N+](=O)[O-])cc1O</smiles>

(II)

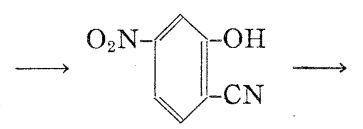

(III)

1) 第 3 回日本化学療法学会 (昭和 30 年 4 月 4 日).

2) M. C, Sannié, M. H. Lapin : Bull. soc. chim. France 1950, 322.

3) R. O. Clinton, et al. : J. Am. Chem. Soc. 74, 592(1952). 


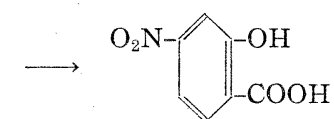

(IV)<smiles>CCCCOC(=O)c1ccc([N+](=O)[O-])cc1O</smiles>

( V)<smiles>[R]Oc1c(C(=O)OCC)ccc([N+](=O)[O-])c1[R]</smiles>
$-\mathrm{COOBu}$<smiles>[R2]Oc1cc([N+](=O)[O-])ccc1C(=O)O</smiles>

(VI)<smiles>[R]c1cc(N)ccc1C(=O)O</smiles>

$$
\mathrm{R}=\mathrm{CH}_{3}, n-\mathrm{C}_{4} \mathrm{H}_{9}, n-\mathrm{C}_{8} \mathrm{H}_{17}, n-\mathrm{C}_{12} \mathrm{H}_{25}, n-\mathrm{C}_{16} \mathrm{H}_{33}
$$

（VI）を得るには (IV) を dialkyl 化した後部分水解すればよいが, 長鎖アルキルの場合は生じたalcohol と (VI) との分離が厄介となり，アルキル化剂子多量を要するので予かじめ $\mathrm{COOH}$ 基を低級アルキル基でエステル 化する方法を採つた。ただしその K-phenolate に脂溶性を与えるためにアルキルとしてブチルを選んだ. 後者

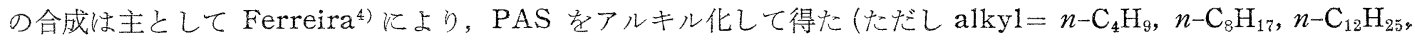
$n-\mathrm{C}_{16} \mathrm{H}_{33}$ ). 両者共低級アルキル体 (ブチル迄) は䖷知物質であるが，この中 N-butyl 体の融点を Grimme 等5) ほ $134^{\circ}$, Ferreira ${ }^{4)}$ は 120 122 と報告している。著者等は追試した結果 Grimme の值が正しいとの結論に達 した。

これら O-alky1 体，N-alkyl 体抢よび中間体として得られた 2-alkoxy-4-nitrobenzoic acid の結核菌に対 する抗菌作用は Fig. 1 亿示す如くで，筆者等が既に報告したアルキル化合物の諸例) と同じく，何れも抗菌力 はアルキル基の炭素数の増加と共に漸時增大し， $\mathrm{C}_{12}$ 付近で極大となり，それ以上では却つて低下している．かつ 極大值での抗菌力は何れも強く, PAS と同程度あるいはそれよりも強力である. 殊に興味あることは 4-nitrosalicylic acid 自体にはさ程の抗菌性は認められないにも拘らず，その alkyl ether はアルキル基が適当の大き さの時に強い抗菌力を有することで，この例は無効とせられている化合物すアルキル基の導入により抗結核性を 持つことのありうることを示するのと考光る。亦た三者の抗菌力は 4-alkylaminosalicylic acid>2-alkoxy-4aminobenzoic acid>2-alkoxy-4-nitrobenzoic acid の順で岗つた。

本研究に協力世られた寺尾昭子, 古賀城一の両氏に感謝する.

\section{実験 の 部}

\section{A 合 成}

2-Methylbenzoxazole (I) o-nitrophenol (工業用) $252 \mathrm{~g}$ 飞 $\mathrm{Ac}_{2} \mathrm{O} 900 \mathrm{cc}$ 飞溶解し活性炭処理後, その $1 / 3$ を 1 L オートクレイヴに入れ，Raney $\mathrm{Ni}$ (合金 $60 \mathrm{~g}$ より作り $\mathrm{Et}_{2} \mathrm{O}$ に䯚濁) を全量の約 $1 / 3$ 加之，水素初圧 $70 \mathrm{~kg} / \mathrm{cm}^{2}$ で約 15 分常温で振盪すれば還元は終る。触媒を沈降させて反応液を抜き, 再び各 $1 / 3$ 量の原料执よび 触葉を加光同様に還元. 計三回反応後全液を集め, 沪過して蒸留し bp $150^{\circ}$ 以上の部分を集め, アルカリ洗浄後 $\mathrm{Na}_{2} \mathrm{SO}_{4}$ 脱水, 隇圧蒸留. $\mathrm{bp}_{24} 96 \sim 99^{\circ}$. 収量 $172 \mathrm{~g}(71.3 \%)$.

5-Nitro-2-aminophenol (II) Sannié 等) にしたがい(I) $70 \mathrm{~g}$ 老冷 conc $\mathrm{H}_{2} \mathrm{SO}_{4} 175 \mathrm{cc}$ に溶解, conc $\mathrm{H}_{2} \mathrm{SO}_{4} 70 \mathrm{cc}+$ 発煙 $\mathrm{HNO}_{3} 60 \mathrm{cc}$ で 20〜25 でニトロ化し 6-nitro-2-methylbenzoxazoleを得. これを約 $12 \%$ $\mathrm{HCl}$ と加温水解して橙赤色の粗製 $(\mathrm{II})$ を得. 収量約 $82 \mathrm{~g}$. 水より再結晶. 黄色針状晶. 150 〜 $165^{\circ}$ で赤変後次 第に暗変し 198 201 2 で分解 (文献值 ${ }^{2}$ ) 198 ～201 分解).

4-Nitro-2-hydroxybenzonitrile (III) Sannié 等にしたがい粗製 (II) $60 \mathrm{~g}$ よう(III) $14.5 \mathrm{~g}$ (45\%) を得.

4-Nitrosalicylic acid (IV) Sannié 等2) にしたがい粗製 (III) $40 \mathrm{~g}$ を $\mathrm{H}_{2} \mathrm{SO}_{4}$ と処理し(IV) $32.5 \mathrm{~g}(73 \%$ ) を得. 水より再結晶。带黄色長針状晶. $\operatorname{mp~} 229 \sim 231^{\circ}$ (文献值 ${ }^{2)} 232 \sim 234^{\circ}$ ).

Butyl 4-nitrosalicylate (V) 粗製 (IV) $10 \mathrm{~g}, \mathrm{BuOH} 60 \mathrm{~g}, \mathrm{H}_{2} \mathrm{SO}_{4} 10 \mathrm{~g}$ を約 16 時間還流乙, 減压下 $\mathrm{BuOH}$ 省去後水を加光て沪別, $2 \% \mathrm{Na}_{2} \mathrm{CO}_{3}$ 溶液で洗浄後含水 $\mathrm{EtOH}$ より反䅇活性炭処理して再結晶. 収量

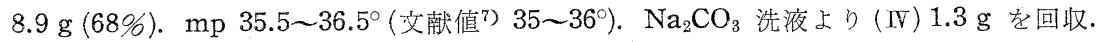

2-Alkoxy-4-nitrobenzoic acid (1) ( $\mathrm{N}) 0.033 \mathrm{~mol}, \mathrm{~K}_{2} \mathrm{CO}_{3}$ 末 $0.051 \mathrm{~mol}$ を脱水キシレン $170 \mathrm{cc}$ と攪拌 下遊離する水を分離しながら水が遊離しなくなる迄還流(約 2 時間)。これに alkyl p-toluenesulfonate $0.1 〜 0.3$ mol を加光，攪汼下遊離する水を分離しながら赤色の消失するまで還流 (7〜13 時間). 冷後結晶学汇別，キシレ ンで洗浔, 沪洗液を $20 \% \mathrm{NaOH}$ で洗浄, 活性炭処理後溶媒を減圧留去, alky1 4-nitro-2-alkoxybenzoate を

4) P.C. Ferreira : Arquiv. biol. 34, 134(1950); C. A. 45, $6604 \mathrm{f}(1952)$.

5) W. Grimme, H. Schmitz：Ber. 84, 734(1951)。 6) 渡辺：本誌 76, 696(1956).

7) I. Kh. Fel'dman, A.M. Eŭdlin, Sbornik Statě̆ : Obschcheř Khim. Akad. Nauk S.S. S. R. 1, 504 (1953); C. A. 49, 959(1955). 
得. その李玉 $50 \% \mathrm{EtOH} 120 \mathrm{cc}$ に溶解し, $\mathrm{Na}_{2} \mathrm{CO}_{3}$ 約 $9 \mathrm{~g}$ を加え攪䢁還流して加水分解(約 1 時間で終る). $\mathrm{EtOH}$ を減圧留去し conc $\mathrm{HCl}$ を加えて生ずる沈殿を集める。取率約 $60 \%$. EtOHより再結晶. 本法により

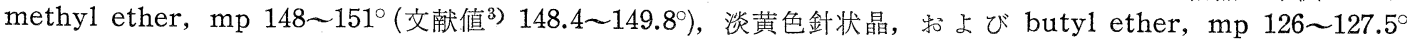
(約 $120^{\circ}$ で sinter) (文献值 ${ }^{3)} 120.9 \sim 122.8^{\circ}$ )，淡黄色針状晶を得.

(2) ( V ) $0.01 \mathrm{~mol}, \mathrm{~K}_{2} \mathrm{CO}_{3}$ 末 $0.017 \mathrm{~mol}$ を脱水キシレン $40 \mathrm{cc}$ と攪拌下遊離する水を分離しながら約 2 時間 還流し, alkyl p-toluenesulfonate $0.011 \mathrm{~mol}$ を加光，赤色の消えるまで同上反応 (5〜15 時間). 後同上処理し て butyl 4-nitro-2-alkoxybenzoate を得. そのま东(1) と同じく加水分解し，EtOH より再結晶. 収率約 55 $\%$. 本法により octyl ether, $\mathrm{mp} 81 \sim 82^{\circ}$ (約 $70^{\circ}$ で sinter), $\mathrm{C}_{15} \mathrm{H}_{21} \mathrm{O}_{5} \mathrm{~N}$ 計算值 $\mathrm{N} 4.75$, 実験值 $\mathrm{N} 4.71$; dodecyl ether, mp 167.5 168.5, $\mathrm{C}_{19} \mathrm{H}_{29} \mathrm{O}_{5} \mathrm{~N}$ 計算值 $\mathrm{N} \mathrm{3.99}$, 実験值 $\mathrm{N} 4.25$; hexadecyl ether, mp 99.5 $102.5^{\circ}, \mathrm{C}_{23} \mathrm{H}_{37} \mathrm{O}_{5} \mathrm{~N}$ 計算值 $\mathrm{N} 3.44$, 実験值 $\mathrm{N} 3.66$ を得. 三者亡も淡黄色針状徵結晶.

2-alkoxy-4-nitrobenzic acid はすべてアルカリ水溶液にとけ，octy1 以上は起泡性が著るしい。

2-Alkoxy-4-aminobenzoic acid nitro 化合物 100 600 mg EtOH $20 \mathrm{cc}$ 飞溶解, Ranney $\mathrm{Ni}$ 約 0.4 $\mathrm{g}$ 学加光, 水素初圧 $40 \sim 90 \mathrm{~kg} / \mathrm{cm}^{2}$, 約 $70^{\circ}$ で $2.5 \sim 3.5$ 時間振盪して還元, 触媒を汇別し, 窒素気流中で滅圧 乾固後 $\mathrm{EtOH}$ より再結晶. 本法によりつぎの化合物を得. methyl ether, mp $149 \sim 150^{\circ}$ (decomp) (文献值 ${ }^{3}$ ) 150.5 151. $4^{\circ}$ (decomp)), 無色針状晶, 収量 $200 \mathrm{mg}$ より $100 \mathrm{mg}$; butyl ether, mp 165.5 167 (decomp)(文 献值 167.6 169.9 (decomp)), 無色短立方体晶, 収量 $600 \mathrm{mg}$ より $370 \mathrm{mg}$; octyl ether, $\mathrm{mp} 73 \sim 74.5^{\circ}$, 無色 針状晶, 収量 $500 \mathrm{mg}$ より $400 \mathrm{mg}, \mathrm{C}_{15} \mathrm{H}_{23} \mathrm{O}_{3} \mathrm{~N}$ 計算値 $\mathrm{N} 5.28$, 実験值 $\mathrm{N} 5.01$; dodecyl ether, mp 86 8 8 ,

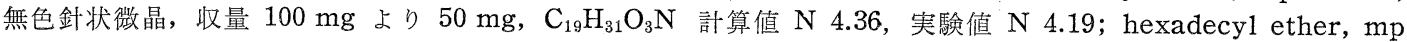

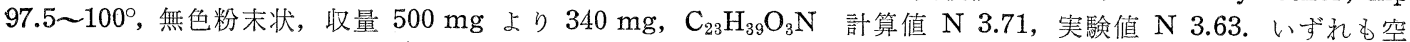
気中では酸化され易い。アルカリ水溶液にとけ, octy1 以上は起泡性が著るしい。

4-Butylaminosalicylic acid ${ }^{* 1)}$ 1) $m$-butylaminophenol ${ }^{* 2)}$ : $m$-aminophenol $6.4 \mathrm{~g}$, butyl $p$-toluenesulfonate $14.7 \mathrm{~g}, \mathrm{NaHCO}_{3} 7.3 \mathrm{~g}$, 水 $15 \mathrm{cc}$, AcOEt $15 \mathrm{cc}$ を 30 〜5 で 5 時間摫拌後 $65^{\circ}$ に上げ $\mathrm{CO}_{2}$ の発生 のなくなるまで (棓泡器による) 加熱. AcOEt で抽出, $1 \mathrm{NHC1} て ゙$ 逆抽出し, $\mathrm{NaOH}$ でリトマス中性とし $\mathrm{Et}_{2} \mathrm{O}$ で抽出, 乾燥, $\mathrm{Et}_{2} \mathrm{O}$ を留去後蒸留し $\mathrm{bp}_{13} 175 \sim 179^{\circ}$ の部分を集める. 収量 $5.5 \mathrm{~g}$. これは未反応の $m$-aminophenol を含有するので $\mathrm{C}_{6} \mathrm{H}_{6}$ に加熱溶解し，析出する $m$-aminophenol を除き母液を乾固してそのままつぎの 反応に利用. 収量 $3.9 \mathrm{~g}$.

2) 4-butylaminosalicylic acid ${ }^{5)}$ : 上記 $m$-butylaminophenol $5 \mathrm{~g}, \mathrm{KHCO}_{3} 10 \mathrm{~g}, \mathrm{KOH} 1.8 \mathrm{~g}$, 水 $10 \mathrm{cc}$

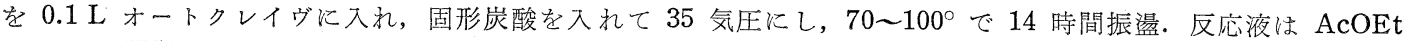
で洗浄後 $\mathrm{HCl}$ で $\mathrm{pH} 4$ とし生ずる沈殿を集めて $\mathrm{EtOH}$ より再結晶. $\mathrm{mp} 134^{\circ}$, 収量 $0.9 \mathrm{~g}(13.4 \%) . \mathrm{C}_{11} \mathrm{H}_{15} \mathrm{O}_{3} \mathrm{~N}$ 計算值 N 6.70, 実験值 N 6.40.

4-Octylaminosalicylic acid PAS (市販 $\mathrm{Na}$ 塩) $3.5 \mathrm{~g}, n-\mathrm{C}_{8} \mathrm{H}_{17} \mathrm{I} 4.8 \mathrm{~g}, \mathrm{EtOH} 20 \mathrm{cc}$ を水浴上 7 時間還流

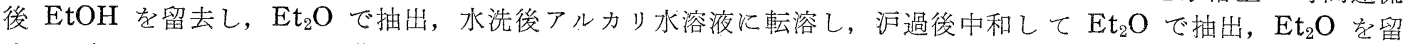
去して得られるシロップに $\mathrm{C}_{6} \mathrm{H}_{6}$ を加えると鱗片状結晶を析出. EtOH より再結晶. $\mathrm{mp} 118$ 121 $1^{\circ}$, 収量 $0.7 \mathrm{~g}$. $\mathrm{C}_{15} \mathrm{H}_{23} \mathrm{O}_{3} \mathrm{~N}$ 計算值 $\mathrm{N} 5.28$, 実験值 $\mathrm{N}$ 5.86. 酸抢よびアルカリに可溶で溶液は起泡性がある.

4-Dodecylaminosalicylic acid PAS (同上) $3.5 \mathrm{~g}, n-\mathrm{C}_{12} \mathrm{H}_{25} \mathrm{Br} 2.5 \mathrm{~g}, \mathrm{EtOH} 16 \mathrm{cc}$, 水 $5 \mathrm{cc}$ を水浴上 6 時間還流後溶媒を留去し, $\mathrm{Et}_{2} \mathrm{O}$ で抽出, $\mathrm{Et}_{2} \mathrm{O}$ 留去後 $\mathrm{C}_{6} \mathrm{H}_{6}$ に加熱溶解し冷却すれば鱗片状晶を析出。 Et $\mathrm{EH}$ り再結晶. $\mathrm{mp} 124 \sim 126^{\circ}$, 収量 $0.5 \mathrm{~g}$. $\mathrm{C}_{19} \mathrm{H}_{31} \mathrm{O}_{3} \mathrm{~N}$ 計算值 $\mathrm{N} 4.36$, 実験值 $\mathrm{N} 4.44$. 酸怙よびアルカリに可溶 で溶液は起泡性が著るしい。

4-Hexadecylaminosalicylic acid dodecyl 化合物と同様にして得. mp 130 - 131. $\mathrm{C}_{23} \mathrm{H}_{39} \mathrm{O}_{3} \mathrm{~N}$ 計算值

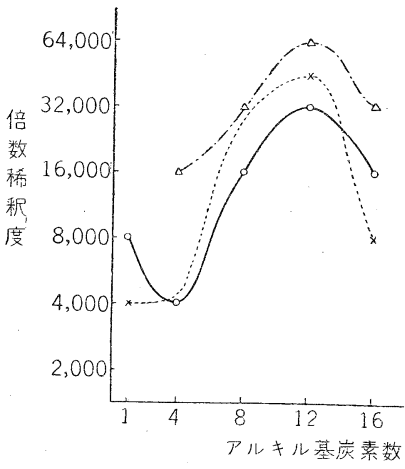

Fig. 1.

Bacteriostatic Power

$\bigcirc-\bigcirc 2$-alkoxy-4-nitrobenzoic acid

$\times \cdots-\cdots \times 2$-alkoxy-4-aminobenzoic acid

$\triangle--\Delta 4$-alkylaminosalicylic acid

*1 PAS をベンゼン中 $n-\mathrm{C}_{3} \mathrm{H}_{7} \mathrm{COH}, \mathrm{AcOH}, \mathrm{Zn}$ 末で還元アルキル化し $\mathrm{mp} 120$ 〜 $122^{\circ}$ のものを得たが，分析 値が理諭值に一致しない。

*2 Grimme 法を S. Hünig：Ber. 85，1056(1952) にしたがい改良した。 
N 3.71, 実験值 N 3.90. 酸拈よびアルカリに可溶で溶液は起泡性が著るしい。

\title{
B 抗菌試験
}

使用菌株は強毒人型菌 Frankfurt 株である。菌は 3 4 週間岡一片倉培地に培養したもの 1 白金耳量を水約 2 cc に浮遊させ，硝子玉で磨砕，遠沈してその上澄約 $0.02 \mathrm{cc}$ を使用した。培地は 10\%山羊血清加 Kirchner 培 地 (培地量 $10 \mathrm{cc}$ ) である. 薬剤はすべて $\mathrm{Na}$ 塩の形で使用した。判定は 3〜4 週間同時培養した後に行なつた。 結果は Fig. 1 亿 2-alkoxy-4-nitrobenzoic acid を○印で, 2-alkoxy-4-aminobenzoic acidを×印で, 4-

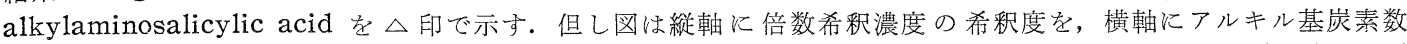
をとつたもので, 曲線は各同族列化合物の抗菌力とアルキル基炭素数との関係を示す.な拈 4-nitrosalicylic acid 㐨よび対照としての PAS の抗菌力㥗それぞれ 1:4,000 执よび 1:32,000であつた.

甲南大学化学科

UDC 615.779.931-011:541.486

278. 坂ロ武一，田ロ清水：テトラサイクリン誘導体の金属キレート化合物 (第 11 報*) テトラサイクリンの金属キレートの単離特よびその性状について

Takeichi Sakaguchi and Kiyomi Taguchi : Metal Chelate Compounds of Tetracycline Derivatives. XI. Studies on the Behavior of Separated Metal Chelate Compound of Tetracycline.

\author{
(Pharmaceutical Faculty, University of Chiba**)
}

Tetracycline-metal chelates were prepared with $\mathrm{Th}^{4+}, \mathrm{Zr}^{4+}, \mathrm{Fe}^{3+}, \mathrm{Cu}^{2+}, \mathrm{Al}^{3+}, \mathrm{Co}^{2+}$, $\mathrm{Mn}^{2+}$, and $\mathrm{UO}_{2}{ }^{2+}$. Their properties, especially their solubility, and method of preparation are described. Tetracycline-Al chelate has a tendency to change rapidly into anhydrotetracycline-Al chelate when it is wet. This change is delayed on the storage of tetracycline-Al chelate shut off from air oxygen. The reason is not fully understood. The chelates isolated are as follows : Tetracycline- $\mathrm{Th}^{4+}$, yellow-orange powder; tetracycline- $\mathrm{Zr}_{\mathrm{r}}{ }^{+}$, yellow-orange vitreous mass; tetracycline- $\mathrm{Al}^{3+}$, yelloworange powder which gradually changes to red; tetracycline- $\mathrm{Cu}^{2+}$, yellow-brown powder; tetracycline-Co ${ }^{2+}$, yellow-brown powder; tetracycline- $\mathrm{Mn}^{2+}$, brown-yellow powder; tetracycline- $\mathrm{UO}_{2}{ }^{2+}$, red vitreous mass; tetracycline-Fe ${ }^{3+}$, black-brown powder.

Infrared spectra of tetracycline- $\mathrm{Th}$ and $-\mathrm{Zr}$ indicated disappearence of carbonyl of $\mathrm{C}-11$ in the tetracycline molecule, and the presence of metal chelate in $\mathrm{C}=\mathrm{O}$ of $\mathrm{C}-11$, which previously had been suggested by the present anthors.

(Received May 7.1957)

著者等は，テトラサイクリン類の金属キレートにつき種々研究を行なつて来て招り，クロルテトラサイクリン (CT) 执よびオキシテトラサイクリン (OT) の単離执よびその性状については先に報告しだ).

今回はテトラサイクリン (TC) の $\mathrm{Th}^{4+}, \mathrm{Zr}^{4+}, \mathrm{Fe}^{3+}, \mathrm{Cu}^{2+}, \mathrm{Al}^{3+}, \mathrm{Co}^{2+}, \mathrm{Mn}^{2+}$ 呿よび $\mathrm{UO}_{2}^{2+}$ 等の金属キレー トを単離し, その $\mathrm{mol}$ 比, 溶解性等につき研究を行ない, あわせて $\mathrm{TC}$ 類の過塩素酸塩の性状招よび $\mathrm{Th} \mathrm{h}^{4+}$, $\mathrm{Zr}^{4+}$ キレートの赤外部吸取スペクトルにつき研究を行なつた。

単離法： TC は強酸, アルカリ, 熱等に不安定な物質であるので, キレート化合物の単離は弱酸性にて行な い緩和な条件のもとで反応せしめた。すなわち $\mathrm{TC}$ 塩酸塩の水またはエタノール溶液に金属の硝酸塩 $\left(\mathrm{Fe}^{3+}, \mathrm{Al}^{+3}\right.$ は塩化物を使用)の水またはエタノール溶液を加えて反応过しめ特に酸, アルカリの添加は行なわない. 金属キレ 一トは溶液または沈殿として得られるから, 溶液の場合はェタノールおよびェーテルによりキレートを沈殿せし める。精製は再結晶が困難であつたので, 再沈殿捻よび洗浄を繰返して行なつた。

単離した金属キレート化合物は特有な色（TC- $\mathrm{Th}^{4+}$ 黄橙色， $\mathrm{TC}-\mathrm{Zr}^{4+}$ 黄色, $\mathrm{TC}-\mathrm{Fe}^{3+}$ 褐色, $\mathrm{TC}-\mathrm{Cu}{ }^{2+}$ カー

* 笌 10 報： 本誌 79, 461(1959).

** Inohana-cho, Chiba.

1) 坂口, 田口, 福島, 小尾: 本誌 78, 177(1958) 